\title{
Evaluation of Performance of Flexible and Floating Drum Biogas Digester for Gas Production at Federal University of Technology Owerri, Nigeria
}

\author{
Ede A.O, Nwazunku A.A, Orji S.M, Abonyi I.C, Okereke E.E, Obasi K.O, Amadi C.O.A, Amadi \\ A.N, Nwankwo C.J, Aronu C.N, Mbaegbu N.
}

\begin{abstract}
An experimental study was carried to test the performance of floating and flexible domestic biogas. Biogas is described as a renewable fuel produced from treatment of waste product. It is rich in methane produced from the fermentation of animal dung, human sewage or crop residues in an air-tight container (digester). The objective of this study was to evaluate the functional and serviceability of the installed domestic biogas in terms of actual feeding versus actual gas production. The laboratory test was carried out at the biotechnology departmental laboratory in Federal University of Technology Owerri. A 90kg of cow dung was weighed with chemical balance and the loading was done in the ratio of 1:1.5 unit volume bases. The domestic biogas parameters were assessed for the performance of the biogas production such as temperature, $\mathrm{pH}$ value, ambient temperature and volume of gas produced. The result of this study was recorded between 26 to $31^{\circ} \mathrm{C}$ for slurry temperature and 30 to $36^{\circ} \mathrm{C}$ for ambient temperature of atmosphere. The $\mathrm{PH}$ value of slurry in the floating type was 8.0, 8.1 for flexible type biogas digester and 7.5 was for fresh prepared one. The volume of the domestic biogas produced was $0.06 \mathrm{~cm} 3$. In this study, the production of domestic biogas was dependent on the following parameter; temperature, $\mathrm{pH}$, solid and ambient temperature. The rate of domestic biogas production was faster at every fresh loaded of cow dung into the digesters. The recommendation in this research study, was to encourage people both rural and urban areas to embrace this technology of waste management.
\end{abstract}

Ede A.O, . Department of Environmental Health, Faculty of Health Sciences and Technology Nnewi Campus, Nnamdi Azikiwe University, Anambra State

Nwazunku A.A, Department of Environmental Health, Faculty of Health Sciences and Technology Nnewi Campus, Nnamdi Azikiwe University, Anambra State

Orji S.M, Department of Public Health, Federal University of Technology, Owerri, Imo State

Abonyi I.C, Department of Environmental Health, Faculty of Health Sciences and Technology Nnewi Campus, Nnamdi Azikiwe University, Anambra State

Okereke E.E, Department of Public Health, Federal University of Technology, Owerri, Imo State

Obasi K.O, Department of Public Health, Federal University of Technology, Owerri, Imo State

Amadi C.O.A, Department of Public Health, Federal University of Technology, Owerri, Imo State

Amadi A.N, Department of Public Health, Federal University of Technology, Owerri, Imo State

Nwankwo C.J, Department of Environmental Health, Faculty of Health Sciences and Technology Nnewi Campus, Nnamdi Azikiwe University, Anambra State

Aronu C.N, Department of Environmental Health, Faculty of Health Sciences and Technology Nnewi Campus, Nnamdi Azikiwe University, Anambra State

Mbaegbu N., Surveillance and Epidemiology Department, Nigeria Centre for Disease Control, Abuja, Nigeria
Index Terms - Solid waste, Anaerobic, Biogas, Digester and Leachate.

\section{INTRODUCTION}

Biogas is a renewable source of energy that can be used as a substitute for natural gas or liquefied petroleum gas. There are different models to assess the energy content of different energy sources, which includes water boiling test, controlled cooking test and kitchen performance test. Biogas is generated when bacterial degrade biological material in the absence of oxygen, in a process known as anaerobic digestion [1]. Since biogas is a mixture of methane (also known as marsh gas or natural gas, $\mathrm{CH} 4$ ) and carbon dioxide, it is a renewable fuel produced from waste treatment. Anaerobic digestion is basically a simple process carried out in a number of steps that can use almost any organic material as a substrate. It occurs in digestive systems, marshes, waste dumps, septic tanks and the Arctic Tundra. Humans tend to make the process as complicated as possible by trying to improve on nature in complex machines but a simple approach is still possible [2].

The concept of biogas production; decomposition of organic wastes under anaerobic conditions ultimately yields biogas as one of the by-products of the process. It indicates that biogas could be produced naturally from decay under water or the guts of animal, or artificially in an air tight digester. As a result, biogas has been described as "a methane-rich gas that is produced from the anaerobic digestion of organic materials in a digester". Itodo \& Philips [3] said biogas is gas rich in methane, which is produced by the fermentation of animal dung, human sewage or crop residues in an air-tight container (digester). Notably the decomposition of organic waste in the absence of air could be elicited by the use of physical or chemical processes at high temperature and/or pressure, or the use of microorganisms at low temperature and atmospheric pressure which dependent on their relative polluting impacts on the environment. However, despite the method used, gas is produced, but is referred to as biogas if generated as a result of the action of microorganisms on the organic wastes [4].

Waste management has becomes global issues in most developing countries like Nigeria. The "Waste-to-Energy (WTE)" concept is gaining more interest in exploring this alternative renewable energy resource. In addition, for biogas to be a renewable and sustainable energy, the type of energy 
resource used for it must be environmentally friendly [5]. Anaerobic digestion is one of the promising technologies to accommodate this requirement due to the advantage of producing fuel gas (methane) as well as generating odour-free residues rich nutrients, which can be used as fertilizers [6].

The role of technology in waste management; wastes contain valuable resource and its potential power is not obtained when utilizing with various improper technologies. This problem can be controlled through use of technologies for treatment that are environment friendly for the processing of waste before its final disposal. These technologies not only lead to generation of substantial quantities of decentralized energy but also reduce the quantity of waste and improving the quality of waste to meet the pollution control standards [7]. Proper treatment option is chosen to utilize these wastes as a raw material to produce some useful material (compost) or energy. The main objective of the treatment option is to utilize the recycling potential and utilization of energy from waste, etc. At the same time, the load on waste management system will also reduce at the disposal site. Most of the countries in the world utilized the option of landfill for the disposal of wastes for a long time. The degradable component of the wastes in the landfill gives rise to the liquid and gaseous end products such as leachate (liquid end product) and biogas [8]. The gaseous products of waste decomposition pollute the air and contribute to global warming. The following methods of treatment such as composting, landfill and recycling, energy recovery seems to be effective because of these advantages; it leads to reduction of waste quantity nearly 60-90\% if proper technology is adopted, it will reduce the demand for the land and reduction of cost of transportation of waste to far away landfill sites.

The public health implications of illegal management of waste can result to emission of toxic gases, proliferation of vectors and green house gases emissions. Burning of waste in open peri-urban (rural-urban) have been a long time waste management method with a view to make treatment and disposal inexpensive. It is burnt either as roadside heaps or at dump sites to reduce waste volume or to recover the recyclable materials [9]. Open burning of household wastes is often reported in developing countries [10]. The open burning also increases annual emissions of green house gases and such situations emit many toxic chemicals and gases such as volatile organic carbonyls and poly aromatic carbonyls [10]. Also, incomplete combustion of hydrocarbons other than $\mathrm{CO}_{2}$ and $\mathrm{CH}_{4}$ in small quantities of other gases are dangerous to human health and can results to cancer, respiratory tract infections [11].

Again, dumping of waste is also in shallow layers around towns and cities are un-aesthetic and can create a potential for parasites and pathogen breeding risks [12, 13]. Although waste may not directly carry large pathogen loads but they promote the growth, multiplication and establishment of various insect, nematodes, annelid and rodent [14].

In terms of green house gases emissions, haphazard waste dumping has been growing at an alarming rate. The shallow open dumping of waste is strongly associated with emissions of methane $\left(\mathrm{CH}_{4}\right)$ and $\mathrm{CO}_{2}$ where methane is a Green house gases (GHG) and more dangerous to human health than that of $\mathrm{CO}_{2}$ [15]. The methane emissions are reported to last many years (20-50 years) after the material has been dumped [16] and its clean-up costs are very high [17].

Despite the various advantages of biogas digesters, there are a few disadvantages to overcome as well. Anaerobic digestion is a slow process, and it requires a long time (>30 days) [18]. Low loading rates and slow recovery after a failure are well defined limitations in biogas production [19]. Also, fluctuation in temperature throughout the year is another challenge of biogas production. The decrease in biogas production during the winter months makes it difficult for cold countries to adapt this technology. In the long-run, people often stop using the household digesters due to lack of knowledge, gas leakage, slow recovery, low gas production, and inadequate supply of substrate [20]. Leakage from biogas digesters increases emissions of methane and carbon dioxide into the environment. Fire explosions in households are another disadvantage when methane leaks from the digester [21].

In Nigeria the following factors limiting the adopting household biogas digesters such as lack of information, lack of availability of raw materials, poor supervision, lack of NGO involvement and lack of skilled labour [22]. Developments in technology can help to rectify these problems by making biogas sustainable for rural energy production. Therefore, the purpose of this research is to evaluate functional and serviceability of the installed domestic biogas in terms of actual feeding versus actual gas production for cooking and boiling.

\section{MATERIALS AND Methods}

Experimental site: The floating and flexible biogas digesters were designed at sunny site of Agricultural Farm land in Federal University of Technology Owerri (FUTO), South East Nigeria. Estimation of methane emission and evaluation of the performances of the domestic biogas digesters were conducted at the study area.

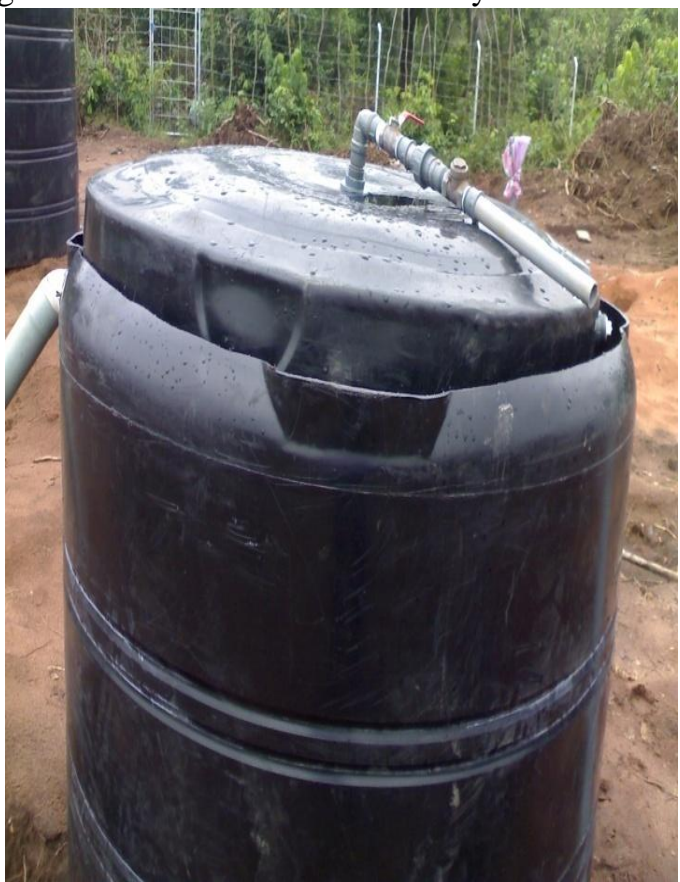




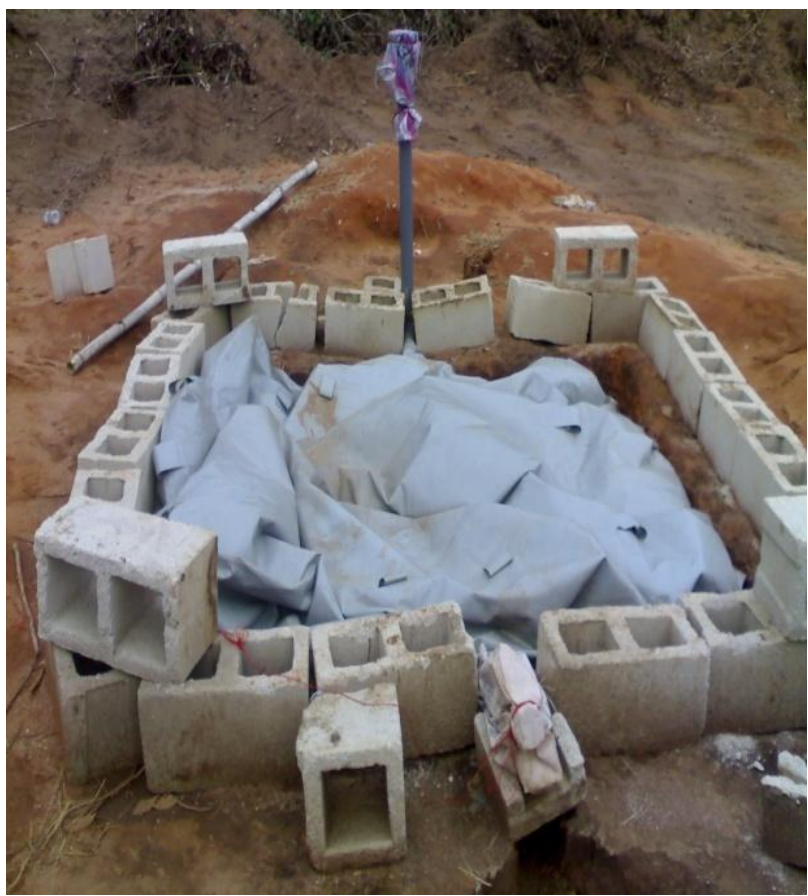

Plate 1: Floating type biogas digester Plate 2: Flexible bag biogas digester

Plate 1\& 2: Illustration of initial installation of floating type and flexible bag biogas digester

The materials used were cow dung, distilled water, infra red thermometer, $\mathrm{pH}$ meter, Biogas digester, measuring tape, measuring cylinder, plastic bucket, filter paper, petris dish, electric ovum, and chemical balance

\section{Loading rate and Sample Collection}

Substrates used for the study was cow dung. The cows were being fed on elephant grass. Cow dung is the undigested residue of plant matter which has passed through the animal's gut. The resultant faecal matter is rich in minerals. Colour ranges from greenish to blackish, often darkening after exposure to air. The cow dung was obtained from the Agricultural Farm, Federal University of Technology Owerri (FUTO) and also from Slaughter house at Obinze, Owerri West LGA, Imo State. The loading of cow dung as estimated amount of raw materials fed per unit volume of digester capacity per week, specifically every Friday for six (6) weeks period. $90 \mathrm{~kg}$ of fresh cow dung was weighed with chemical balance and resulted to four (4) buckets (paint type) of fresh prepared cow dung which were fed into flexible bag digester and floating type till the fed reached the brim and ready to flow out from the outlet pipe. The loading was done in the ratio of 1:1.5 unit volume bases (that is one bucket of cow dung to one and half bucket of water) for fresh dung. The mixture was done in the above mentioned ratio to arrive at the desired consistency of the inputs. A sample from fresh prepared cow dung, sample from floating type biogas digester and sample from flexible type biogas digester were collected with $75 \mathrm{cl}$ of empty plastic Eva water and transfer to laboratory for analysis.

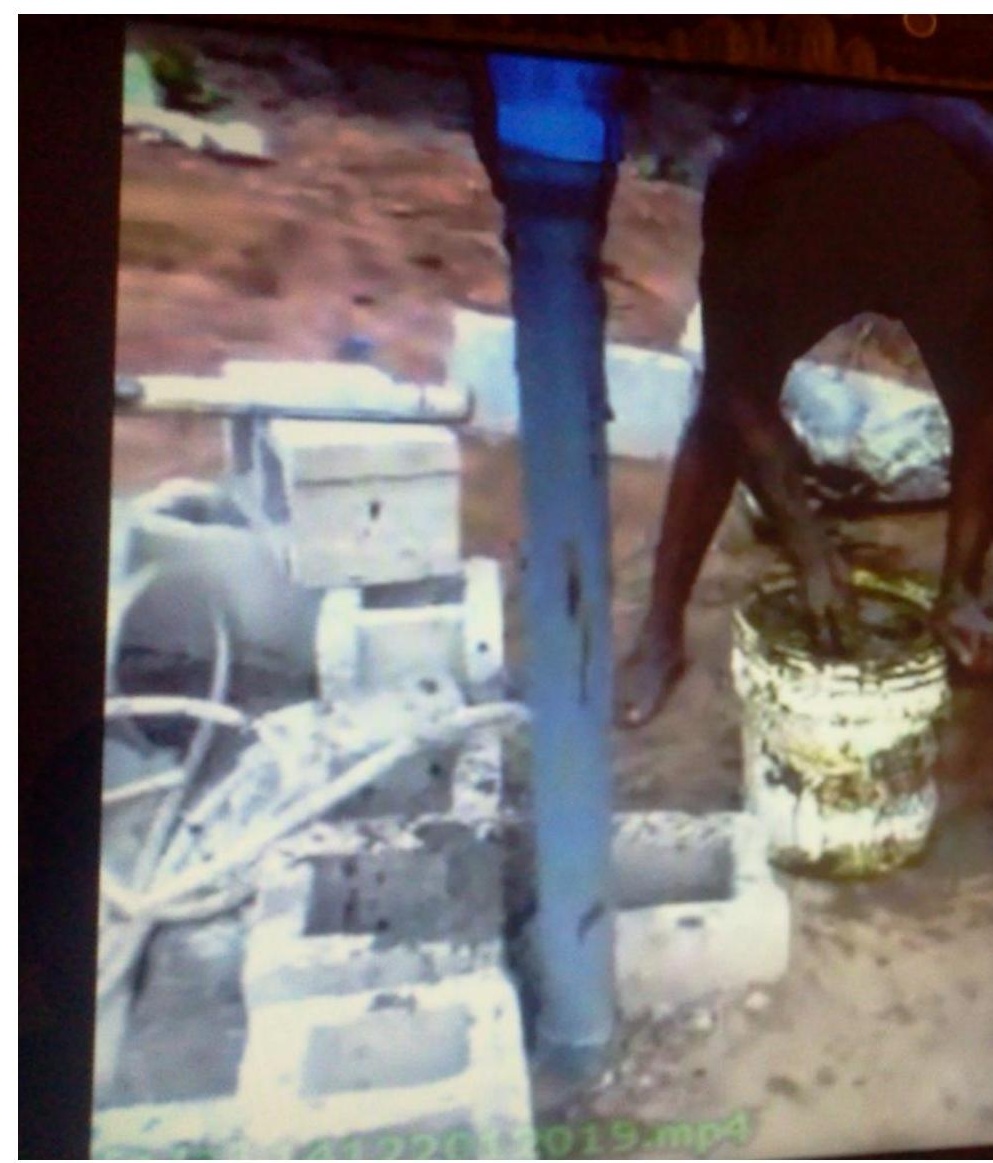

Plate 3: Illustration of mixture process of cow dung for both floating and flexible type biogas digester

Measurement of Parameters

Different parameters like ambient temperature, slurry temperature, average $\mathrm{pH}$ values and average volume of the gas are measured on weekly basis. These data have been taken at the interval of 5 days for six (6) weeks on hours between 10:00 am to 3:00 pm due to presence of solar radiation. Under the analysis, the average of solar intensity and relative humidity at these different readings in a week for six weeks, until the biogas production inside the biogas chamber stop. In this manner, average calculated ambient temperature and average slurry temperature was $26^{\circ} \mathrm{C}$ to $35^{\circ} \mathrm{C}$, ambient temperature was between $34^{\circ} \mathrm{C}$ and $40^{\circ} \mathrm{C}$. The production rate and methane fraction has also been observed under the influence of various temperature ranges in dry season in South East, Nigeria.

Height/volume of gas production: The height of the effective gas storage part as seen in plate 4 and 5 are sometimes named as pressure weight or volume of the gas, was $0.23 \mathrm{~m}$ at the initial day. A calibrated measuring tape was used to measure the reading of the gas production from the digester. 


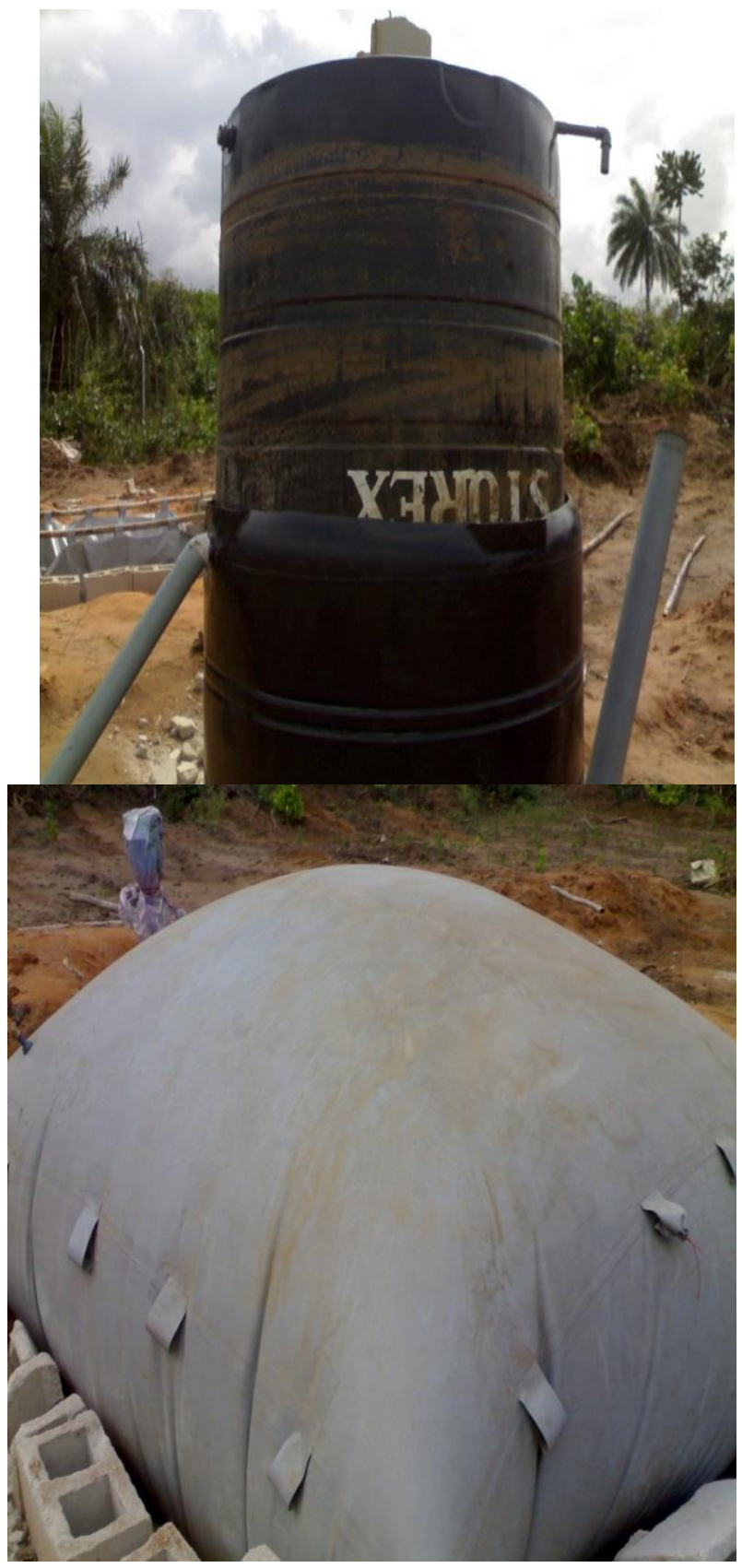

Plate 4: Floating type digester bag digester

Plate 4 \& 5: Picture of Gas produced in floating type digester and flexible type digester

The volume of domestic biogas produced was measured by computing the volume of the gas holder floating over water level in the outer drum. The base area of the gas holder is expressed by equation (1)

$A=\pi d^{2} / 4=\pi \times 0.25^{2} / 4=0.0491 \mathrm{~m}^{2}$

The height of the inner drum above water level was read off on the tape attached to the gas holder. This height $(\mathrm{h})=\mathrm{x}$, which varies.

Volume of biogas is obtained as the volume of inner drum above water level, given by equation (2)

Volume, $V=\left(\pi d^{2} / 4\right) h$

Where $\mathrm{h}=x$

Substituting for $\mathrm{A}$ in equation (1),

$\mathrm{V}=0.0491 x \mathrm{~m} 3$

$\mathrm{V}=0.0491 \times 0.23=0.0113 \mathrm{~cm}^{3}$

Where $\mathrm{V}=$ Volume of biogas
$\mathrm{P}^{\mathrm{H}}$ Values: During this stabilization period, digester temperature of 26 to $35^{\circ} \mathrm{C}$ was monitored and $\mathrm{pH}$ was maintained in the range of 6.5 to 8.5 . The $\mathrm{P}^{\mathrm{H}}$ values of the slurry inside the digester indicate the concentration of hydrogen in the digester as to be suitable for effective anaerobic digestion process. The $\mathrm{P}^{\mathrm{H}}$ value of slurry in the floating type was 8.0, 8.1 for flexible type biogas digester and 7.5 was for fresh prepared cow.

\section{RESULTS}

From the anaerobic digestion, three different temperature ranges are identified depending on the suitable range for microorganisms to grow and metabolize the substrate available and such temperatures are psychrophilic, temperature from $10^{\circ} \mathrm{C}$ to $25^{0} \mathrm{C}$, mesophilic, temperature from $25^{\circ} \mathrm{C}$ to $35^{\circ} \mathrm{C}$ and thermophilic, temperature from $49^{\circ}$ $\mathrm{C}$ to $60^{\circ} \mathrm{C}$.

The microorganism associated with the situation to live and be active at those temperature ranges are termed Psychrophiles, Mesophiles and Thermophiles respectively. Temperature ranges of microorganism as stated above showed a relative growth rate.

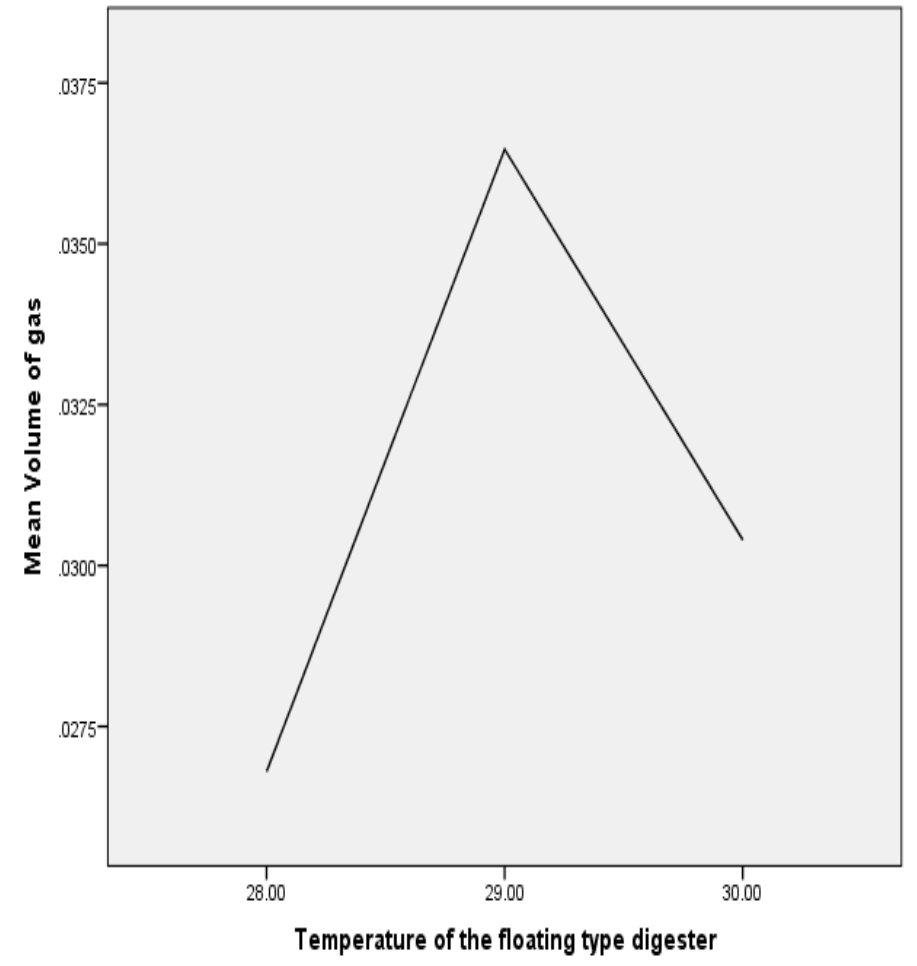

Figure 1: Effect of temperature on biogas production $\left(\mathrm{cm}^{3}\right)$ in the floating type digester

The Figure 1 shows a gradual increase in biogas production from $0.0534 \mathrm{~cm}^{3}$ to $0.0368 \mathrm{~cm}^{3}$ before the declining stage take place due low fresh substrate. This is an indication of effect of temperature on biogas production. Since AD process can take place at difference temperature. The results of this analysis as obtained to be $27^{\circ} \mathrm{C}$ to $30^{\circ} \mathrm{C}$ were in the same range to that of Mesophilic bacteria described in many scientific literatures with optimum temperature $25^{\circ} \mathrm{C}$ to $35^{\circ} \mathrm{C}$ respectively. 


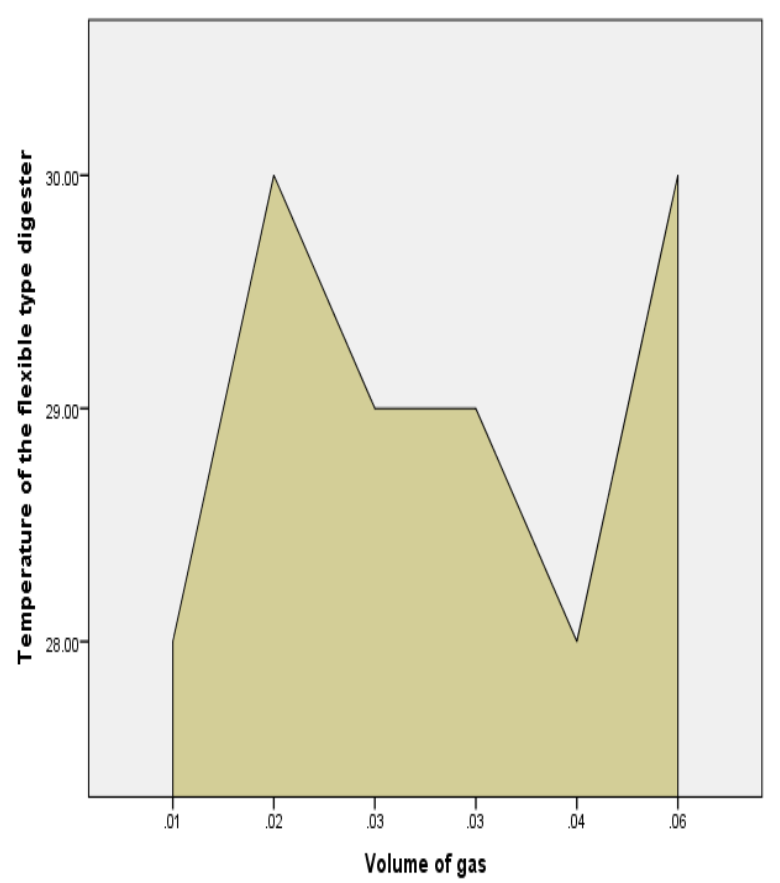

Figure 2: Effect of temperature on biogas production $(\mathrm{cm} 3)$ in the flexible type digester

The temperature is not stable in anaroebic digester, the operation temperature in flexible digester flucate inside the digester as figure 2 indicated above. It shows the rates of relative biogas yields depending on temperature and retention time. Operation temperature influences the toxicity of ammonia. When decreasing the temperature to $30^{\circ} \mathrm{C}$ or below, the growth rate of the mesophilic microogranisms will drop drastrically as indicated in $0.04 \mathrm{~cm}^{3}$, and the risk of wash out of the microbial population can occur, due to a growth rate lower than the actual higher rention time (HRT). From the graph above, experience shows that the high loading or at low HRT, a mesophilic operated digester has higher gas yield and higher conversion rates.

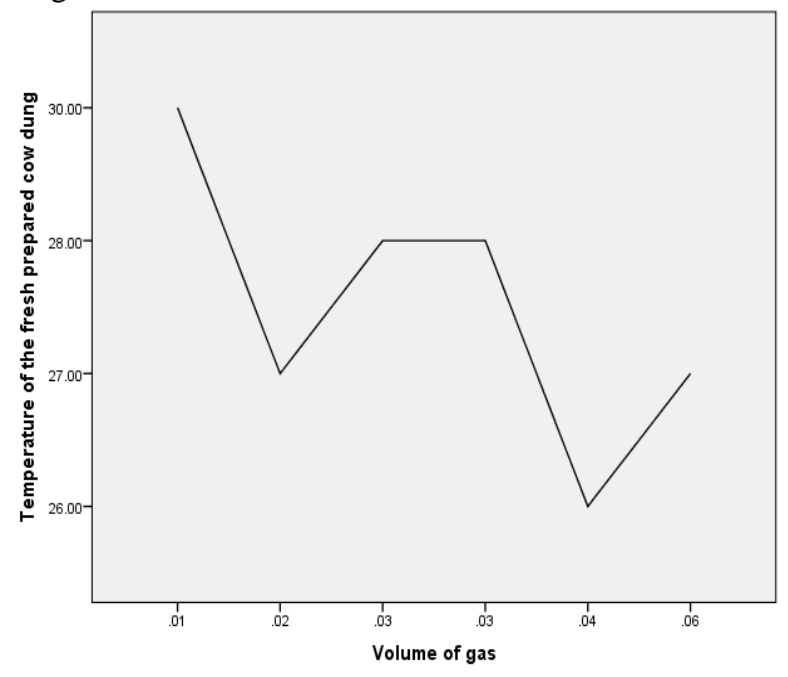

Figure 3: Effect of temperature on biogas production $(\mathrm{cm} 3)$ in fresh Cow dung

Due to changes in climatic condition the biogas production with fresh cow dung have different variations as it increases at $0.009 \mathrm{~cm}^{3}$ and decrease at $0.02 \mathrm{~cm}^{3}$. It also increases after a fresh load of cow dung at $0.03 \mathrm{~cm}^{3}$ and decreases again at

\section{$0.0402 \mathrm{~cm}^{3}$ as all seen in the figure 3 .}

\section{The $\mathbf{p H}$ Value of biogas production}

The $\mathrm{pH}$ is also important parameter and the acceptable values of pH 6.2 exist as minimum before the enzymatic activity of the methane forming bacteria stopped because the $\mathrm{pH}$ fluctuates.

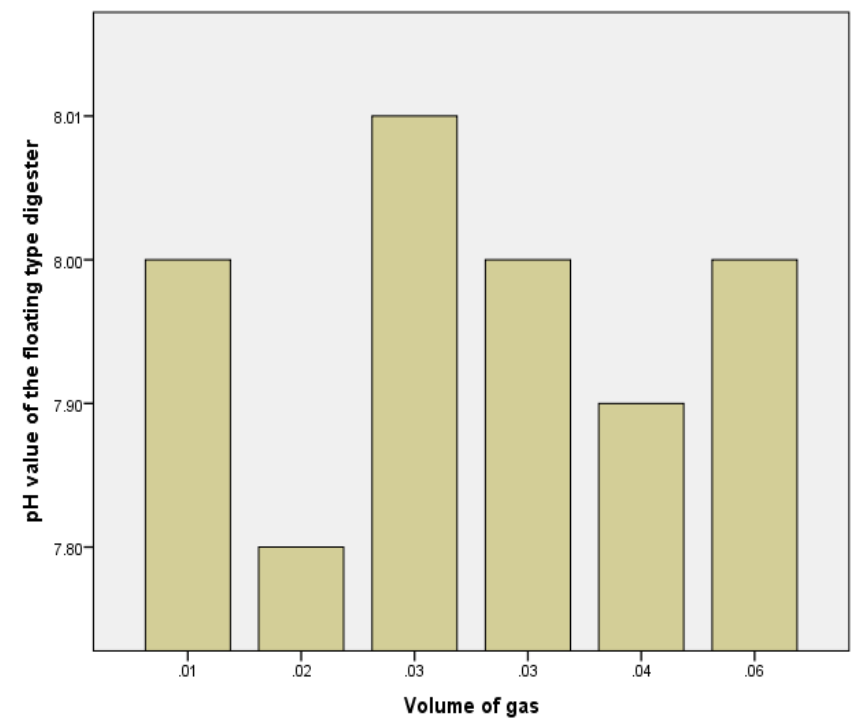

Figure 4: Effect of pH values on biogas production $(\mathrm{cm} 3)$ in floating type digester

In figure 4 , the $\mathrm{pH}$ has highest at 8.0 and lowest at 7.7 with corresponding gas production of $0.03 \mathrm{~cm}^{3}$ and $0.02 \mathrm{~cm}^{3}$ respectively.

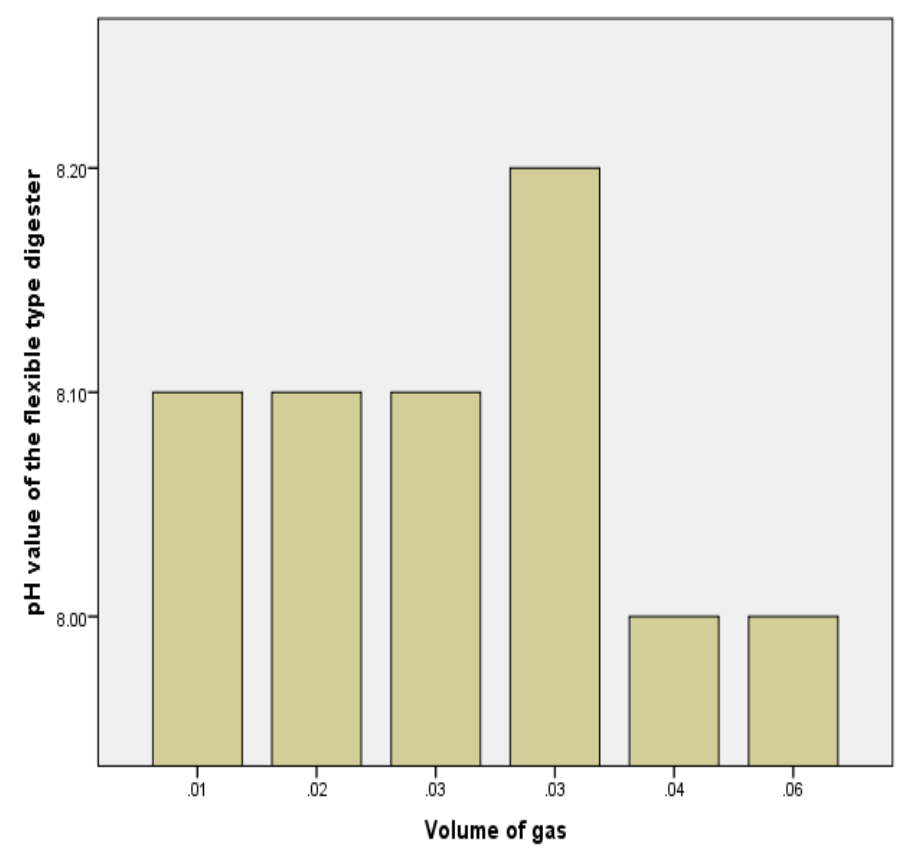

Figure 5: Effect of pH values on biogas production $(\mathrm{cm} 3)$ in flexible type digester

In figure 5, the $\mathrm{pH}$ has highest at 8.2 and lowest at 8.0 with corresponding gas production of $0.03 \mathrm{~cm}^{3}$ and $0.04 \mathrm{~cm}^{3}$ and $0.06 \mathrm{~cm}^{3}$ respectively. 


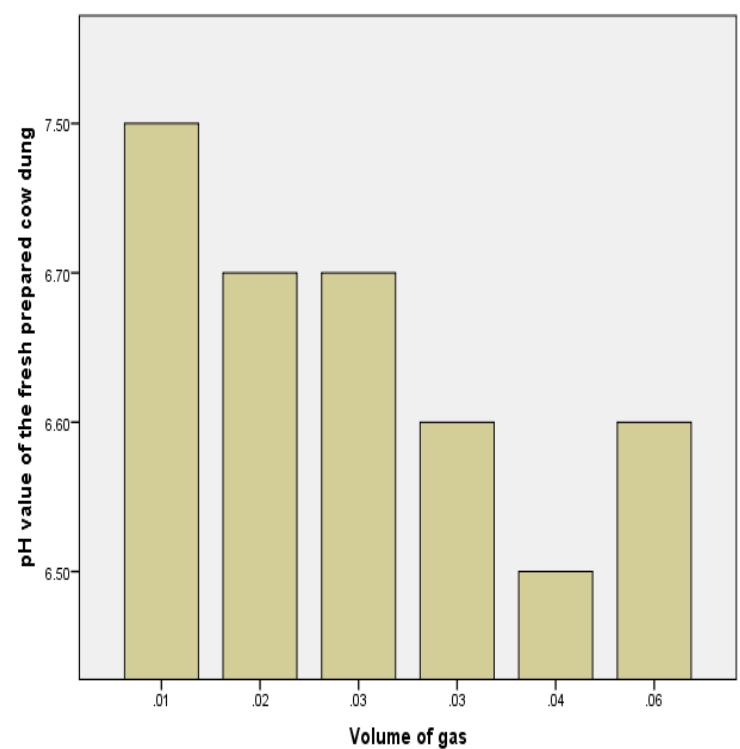

Figure 6: Effect of $\mathrm{pH}$ values on biogas production (cm3) in fresh cow dung

In figure 6 , the $\mathrm{pH}$ has highest at 7.5 and lowest at 6.5 with corresponding gas production of $0.01 \mathrm{~cm}^{3}$ and $0.04 \mathrm{~cm}^{3}$ respectively.

In the above figure 4,5 and 6 , a properly operated anaerobic digestion should have a $\mathrm{pH}$ values between 6.5 and 8.5. Therefore, $\mathrm{pH}$ values in this research ranges from 6.5 to 8.2 which indicate the optimum gas production.

\section{DISCUSSION}

In this study, it has been observed that the production of biogas is dependent upon the temperature, $\mathrm{pH}$ and the solar intensity of the atmosphere. The gas production was found to increase at initial weeks and then become constant and started increasing again after a fresh load of substrate. The variation of solar intensity for the study period may be due to cloudy weather condition, because the monsoonal season is also fluctuating. All these parameters shown in the study play a significant difference in biogas production. Biogas production was monitored and measured for biogas fluctuation which was in accordance with the method adopted by Yusuf et al, [23].

In order of performance, flexible digester could be rated as the most efficient and followed by floating type digester respectively. In other words, specific biogas production per gram of volatile solid added to flexible digester is higher than floating digester. This suggests that high concentration of anaerobic bacteria works effectively to degrade organic substrate from flexible digester. Biogas is low at the beginning and fluctuates depending on the feeding rate as observed during the study; this indicated that the biogas produced in batch conditions corresponds to specific growth rate of methanogenic bacteria [24].

The graphs in the study showed the volume of biogas production with temperature for each digester. According to Jagadish et al, [24], it can be observed from the figures, that biogas production rate tends to obey sigmoid function (S-Curve). Sadaka \& Engler [25], opined that water content is one of the parameter affecting anaerobic digestion of solid wastes. There are two main reasons namely: Water makes possible the movement and growth of bacteria facilitating the dissolution and transport of nutrient. Water also reduces the limitation of mass transfer of non homogenous or particulate substrate. The variation in temperature and $\mathrm{pH}$ as observed during the study period could be attributed to climatic condition of the study days towards the digestion period after loading of fresh substrate and directly or indirectly affects digester.

\section{CONCluSions}

In this experiment, it has been observed that the domestic biogas plant is successful technological method of waste management under a temperature of not less than $25^{\circ} \mathrm{C}$. The fluctuations observed in the volume of biogas produced may be attributed to the change in metabolism of the bacteria in response to the fluctuations in the temperature and $\mathrm{pH}$ of the digestion medium. The plastic and rubber made biogas digester is good one because they are more durable, less prone to corrosion, light in weight and more heat absorbing capacity, so it maintains sufficient temperature inside the digester which increases the rate of production of biogas. This new technology of waste management is economically feasible for developing country like Nigeria.

\section{RECOMMENDATIONS}

The recommendations include encouraging people both rural and urban to embrace this new technology of waste management because of its importance in achieving these specific goals.

In terms environmental sustainability, it helps in boosting agricultural productivity, reducing deforestation for industrial fuels, reducing greenhouse gas emissions

Concerning economy, it helps in cutting down poverty and hunger level by reducing income spent on cooking and lighting, it makes available resources job creation for people.

On health aspect, it providing access to better medical facilities for maternal care in terms of light provision, it also allow for medicine refrigeration and equipment sterilization.

For education, it provides light in schools for reading and studying and creates more child friendly environment (access to clean water, sanitation, lighting and heating (cooking) which can improve attendance in school and reduce dropout rates.

In gender equality and women's empowerment, biogas technology helps in freeing women's time from survival activities, reducing exposure to indoor air pollution and improving health among gender and providing lighting for home study and the possibility of holding evening classes. Finally, more research into these issues is highly needed.

\section{ACKNOWLEDGEMENT}

We acknowledge the Department of Public Health, Federal University of Technology, Owerri for approval of this work and people in Biotechnology Laboratory. Our special thanks to Prof. A.N. Amadi. Many appreciations go to Environmental health Officer Registration Council of Nigeria and Prof. Srihdar for their contributions. 


\section{CONFLICTS OF INTERESTS}

The authors declare no conflict of interest. There is no conflict in the design of the study; data collection, analyses, or interpretation of data; writing of the manuscript, and final decision to publish the results.

\section{REFERENCES}

[1] Ilaboya, I.R., Asekhame,F.F., Ezugwu, M.O.,Erameh ,A.A. \& Omofuma,F.E., Studies on Biogas Generation from Agricultural Waste; Analysis of the Effects of Alkaline on Gas Generation. World Applied Sciences Journal, 2010, 9 (5): 537-545.

[2] Fulford, D. Biogas Stove Design: A short course. University of Reading, U.K, 1996.

[3] Itodo, I. N \& Phillips, T. K. Nomograph for determining temperatures in anaerobic digesters from ambient temperatures in the tropics. Agricultural Engineering International: journal, 2007, 9:10.

[4] Alfa, I.M. C.A. Okuofu, D.B. Adie, S.O. Dahunsi, U.S. Oranusi \& Idowu, S.A. Evaluation of biogas potentials of cymbopogon citratus as alternative energy in Nigeria. International Journal of Green Chemistry and Bioprocess. 2012, 2(4): 34-38. Available online at http://www.urpjournals.com. Date retrieved; 10 December, 2013

[5] Brown, P., Kete, N \& Livernash, R. Forest and land use project. In: Goldemberg, Journal. (Ed.), Issues and Options: The Clean Development Mechanism, United Nations Development Programme, New York; 1998.

[6] Karim, K., Hoffmann, R., Klasson, K.T \& Dahhan, M.H. Anaerobic digestion of animal waste: Effect of mode of mixing. Water Research, 2005, 39:3597-3606.

[7] Morris, G. R. Anaerobic fermentation of animal astes: kinetic and empirical evaluation. M.S.Thesis, Cornell University,Ithaca, New York, 2003.

[8] Jaffrin, A., Bentounes, N., Joan, A.M., Makhlouf, S. Landfill biogas for heating greenhouses and providing carbon dioxide supplement for plant growth. Bio systems Engineering. 2003, 86:113-123.

[9] Srinivas, R. State of the environment report and action plan, 2003, Karnataka.

[10] Lemieux, P.M., Lutes, C.C., Santoianni, D.A. Emissions of organic air toxics from open burning: a comprehensive review. Progress in Energy and Combustion Science, 2004, 30: 1-32.

[11] Amadi, A.N. ABC of Environmental Health. Owerri. Readon Publishers Ltd, 104 Tetlow Rd.Nigeria. 2011, p28-37.

[12] Linn-Gulbrandsen. Development Implications and Sustainability of Biogas Plants in Njombe District, Tanzania. Master Thesis in International Environmental Studies Norwegian University of Life Sciences, 2011.

[13] Shekdar, A.V, Municipal solid waste management - the Indian perspective. Journal of Indian Association for Environmental Management, 1999, 26 (2), 100-108.

[14] Van Lier, J. B \& Rebac, S. High-rate anaerobic wastewater treatment under psychrophilic and thermophilic conditions. Water Science and Technology, 1997, 35(10): 199-206

[15] International energy agency (IEA). Municipal solid waste and its role in sustainability. Biomass and Bioenergy, IEA, 2004.

[16] Aitchison, E. Methane generation from UK landfill sites and its use as anenergy resource. Energy conversion and management; 1996, 37: 1111-1116.

[17] Gupta, S., Mohan, K., Prasad, R., Gupta, S., Kansal, A. Solid waste management in India: options and opportunities. Resources, Conservation and Recycling, 1998, 24:137-154.

[18] Martins das Neves, L.C., Converti, A \& Vessoni-Penna, T.C. Biogas production: New trends for alternative energy sources in rural and urban zones. Chemical Engineering Technology; 2009, 32:1147-1153.

[19] Tang, W.Z. Physicochemical Treatment of Hazardous Wastes; Lewis publisher: Boca Raton, FL, USA, 2004.

[20] Wijesinghe, L.C.A.D.S., Chandrasiri, J.A, Operating experience with biogas plants in Sri Lanka. Nat. Resour. Forum, 1986, 10: 221-229.

[21] Khoiyangbam, R.S. Environmental implications of biomethanation in conventional biogas plants. Iran Journal of Energy and Environment; 2011, 2:181-187.

[22] Ojolo, S., Bamgboye, I Ogunsina., Oke S.A Analytical Approach for Predicting Biogas generation in a Municipal Solid Waste anaerobic digester, 2008, 1148-1248

[23] Yusuf, M.O.L., Debora, A., and Ogheneruona, D.E. Ambient Temperature Kinetic Assessment of Biogas Production from Co-digestion of Horse and Cow dung. Resources,Agriculture and Engineering, 2011. 57(3):97-104.
[24] Jagadish, H., Malourdu, A.R., Muralidhara, P.L., Desai, S.M., and Mahadeva, G.K. Kinetics of Anaerobic Digestion of Water Hycinth using Poultry Litter as Inoculums. International Journal of Environmental Science and Development, 2012, 3:2

[25] Sadaka, S.S., and Engler, C.F. Effect of Initial Total Solid on Composting of Raw Manure with Biogas Recovery. Composite Science and Utilization, 2003, 11(4), 361-369. 